Г. А. Базарова, В. Ц. Аыксокова

РУКОВОАИТЕАИ БУРЯТСКОГО ФИАИААА

СИБИРСКОГО ОТАЕАЕНИЯ АКААЕМИИ НАУК СССР БУРЯТСКОГО НАУЧНОГО ЦЕНТРА СИБИРСКОГО ОТАЕАЕНИЯ РОССИЙСКОЙ АКААЕМИИ НАУК (1966 - по н. в.)

Статья посвящена актуальной проблеме истории региональной науки - деятельности руководителей Бурятского филиала Сибирского отделения Академии наук СССР, а затем Бурятского научного центра СО РАН. На основе архивных документов, материалов периодической печати через призму биографических данных руководителей рассматриваются основные этапы профессионального, научного пути, вклад каждого в создание и развитие научного учреждения, в основные направления его деятельности.

Ключевые слова: Бурятия, научный центр, президиум, Сибирское отделение, научно-организационная деятельность, научный потенциал.

\author{
G. D. Bazarova, V. Ts. Lyksokova
}

\title{
HEADS OF THE BURYAT SUBSIDIARY OF THE SIBERIAN BRANCH OF THE ACADEMY OF SCIENCES OF THE USSR - BURYAT SCIENTIFIC CENTER OF THE SIBERIAN BRANCH OF THE RUSSIAN ACADEMY OF SCIENCES (1966 - PRESENT)
}

The article is devoted to the actual problem of the history of regional science - the activity of the heads of the Buryat branch of the Siberian branch of the Academy of Sciences USSR, and then the Buryat scientific center of the SB RAS. Based on the archival documents and materials of periodicals the main stages of professional, scientific ways and the contirbution of each leader in the formation and development of scientific institution (in the main direction of its activities) are examined through the prism of biographical data of the heads.

Keywords: Buryatia, scientific center, Presidium, Siberian branch, scientific and organizational activity, scientific potential.

$\mathrm{O}$ дной из главных задач созданного в 1957 г. Сибирского отделения АН СССР стало формирование кадрового потенциала академических учреждений на востоке России. Сталинское выражение «Кадры решают все» очень хорошо характеризует роль руководителей тех лет в решении множества задач, от выполнения которых зависела как работа самих учреждений, так и судьба научных сотрудников.

Руководители Сибирского отделения СО РАН вдумчиво подходили к подбору руководящего состава научных центров. Важна была как профессиональная, научная квалификация руководителя, так и его управленческие качества.

БАЗАРОВА Галина Дашиевна - кандидат исторических наук, председатель Федерального государственного бюджетного учреждения науки «Бурятский научный центр СО РАН» (Улан-Удэ, Россия). E-mail: gdbazarova@mail.ru.

ЛЫКСОКОВА Вера Цэдашиевна - доктор исторических наук, заведующая научным архивом Федерального государственного бюджетного учреждения науки «Бурятский научный центр СО РАН» (Улан-Удэ, Россия). E-mail: lverased@yandex.ru. 
Отечественная история

Рассматривая деятельность Бурятского научного центра СО АН СССР и СО РАН в исторической ретроспективе, важно отметить, что у истоков формирования и развития Бурятского научного центра, созданного на базе Бурятского комплексного научно-исследовательского института, стояли авторитетные ученые, фамилии которых были уже известны научной общественности Сибири, но, к сожалению, незаслуженно забываются сегодня. Данная статья представлена в формате биографических справок о жизни и деятельности всех руководителей Бурятского научного центра, сформированных на материалах научного архива БНЦ СО РАН. Основу составляют сведения биографического характера, отражается трудовая, научная, педагогическая, производственная деятельность с указанием должностей, места и времени работы в различных учреждениях. Описаны также направления исследований руководителей, их вклад в научно-организационную деятельность, награды и достижения.

В сентябре 1966 г. было принято постановление об организации Бурятского филиала СО АН СССР. В состав филиала вошли Бурятский институт естественных наук, Бурятский институт общественных наук, 3 общих вспомогательных подразделения, научная библиотека, редакционно-издательский отдел и музей. Административно-управленческая часть была общей для филиала и обоих институтов.

Постановлением Президиума АН СССР от 9 сентября 1966 г. № 602 председателем Президиума БФ СО АН СССР был назначен д.г.-м.н., проф. Олег Владимирович Макеев (15.08.1915 - 13.08.1999).

О. В. Макеев родился 15 августа 1915 г. в г. Троицкосавске (переименован в г. Кяхта в 1934 г.). Отец - Владимир Александрович Макеев, инженер; мать - Вера Федоровна Макеева (урожд. Смирнова), учительница, музейный работник. Детство прошло в г. Кяхте. Окончил девятилетнюю школу.

После окончания школы работал счетным и складским работником. С 1935 по 1940 г. учился в Иркутском государственном университете (ИГУ), в 1940 г. окончил геолого-почвенно-географический факультет с отличием и был зачислен в аспирантуру, которая прервалась в 1941 г. в связи с начавшейся войной. Был призван в армию, прошел всю войну, закончил ее в звании майора. За боевые заслуги в Великой Отечественной войне награжден тремя орденами и двумя медалями.

Олег Владимирович вернулся к научной работе в 1945 г. и стал заниматься изучением почв Иркутской области, Бурят-Монгольской АССР и Монгольской Народной Республики. В 1949 г. защитил диссертацию на тему «Подзолообразование на различных породах Среднесибирского плоскогорья» и ему присуждена ученая степень кандидата геолого-минералогических наук. В 1950 г. он утвержден в ученом звании доцента. Работал на кафедре почвоведения Иркутского государственного университета, возглавлял ряд научных экспедиций и отрядов по исследованию почв Иркутской области и Бурятской АССР, в частности руководил систематическими исследованиями по теме «Плодородие почв Иркутской лесостепи».

В 1955-1957 гг. Олег Владимирович учился в докторантуре при МГУ им. М. В. Ломоносова, где работал над темой «Дерновые таежные почвы юга Средней Сибири (генезис, свойства и пути рационального использования)». В 1958 г. успешно защитил диссертацию на соискание ученой степени доктора геолого-минералогических наук. Работа получила высокую оценку в статье министра высшего и специального среднего образования СССР проф. В. П. Елютина, опубликованной в газете «Известия» [НА БНЦ СО РАН. Ф. 3. ОП. 4. Д. 33 (л/д). Л. 35].

В связи с организацией БКНИИ СО АН СССР в 1958 г. О. В. Макеев был приглашен туда заведующим отделом почвоведения, с 14 июля 1959 г. - заместителем директора по научной работе, с 24 ноября 1960 г. - директором института.

В 1966 г. после преобразования БКНИИ в Бурятский филиал СО АН СССР О. В. Макеев назначен председателем Президиума филиала и директором Бурят- 
ского института естественных наук. В связи с истечением срока полномочий постановлением Президиума СО АН СССР от 20 февраля 1969 г. была удовлетворена просьба О. В. Макеева об освобождении его от обязанностей председателя Президиума БФ СО АН СССР и директора БИЕН [НА БНЦ СО РАН. Ф. 3. ОП. 4. Д. 33 (л/д). Л. 87].

О. В. Макеевым проведены исследования по изучению эффективности микроэлементов в растениеводстве, по влиянию микроэлементов на микробиологическую деятельность почв. Под его руководством в 1963 г. в Улан-Удэ проводится первая научно-производственная конференция по борьбе с эрозией почв в Бурятской АССР с широким участием научных организаций областей и краев Советского Союза. Он принимает участие в ряде международных научных мероприятий: был делегатом VIII Международного конгресса почвоведов в Румынии в 1964 г., третьего Национального конгресса почвоведов в Югославии в 1966 г., Международного симпозиума по радиоэкологии в Швеции в 1966 г. Организовал ряд экспедиций в Монгольской Народной Республике.

О. В. Макеев - автор и соавтор более 70 научных работ. Его труды посвящены широкому кругу научных вопросов, охватывающему географию, генезис и агропроизводственную характеристику почв Средней и Восточной Сибири, агрохимию и биогеохимию микроэлементов, эрозию почв в Сибири и на Дальнем Востоке. Он является автором и соавтором ряда почвенно-географических карт Иркутской области и Бурятской АССР, также схем и работ по агропочвенному районированию [Там же. Д. 30 а (л/д). Л. 58-60, 78, 88-89]. Основными направлениями БИЕН под его руководством были: изучение проблем почвоведения, биологической роли микроэлементов, разработка биологических основ интенсификации растениеводства, животноводства и лесного хозяйства, геологическое исследование территории Забайкалья и др. Он один из инициаторов преобразования БКНИИ в филиал Сибирского отделения [Научные центры 2006: 24].

О. В. Макеев был опытным педагогом-руководителем аспирантов. Им подготовлены многие почвоведы и агрохимики в ИГУ и БГСХИ. В БГСХИ по его инициативе и поддержке было создано отделение почвоведения и агрохимии.

О. В. Макеев наряду с научной и педагогической деятельностью выполнял большую общественную работу. Член КПСС с 1944 г., в 1947 г. избран председателем Иркутского обкома союза работников высшей школы. Во время работы в университете был секретарем парторганизации биолого-почвенного факультета, членом факультетского и университетского партбюро, редактором многотиражной газеты «За научные кадры» [НА БНЦ СО РАН. Ф. 3. Оп. 4. Д. 33 (л/д). Л. 31-32]. Член Бурятского обкома КПСС, в 1963-1967 гг. - депутат Верховного Совета Бурятской АССР, председатель Бурятского отделения Всесоюзного общества почвоведов, член научного совета по проблемам микроэлементов в растениеводстве и животноводстве АН СССР. В 1965 г. О. В. Макееву было присвоено почетное звание «Заслуженный деятель науки и техники Бурятской АССР».

В период его руководства была установлена структура и основные направления научных исследований в БФ СО АН СССР. Филиал посетили известные академики, ученые СССР, делегации и ученые из Индии, Франции, Монголии, Японии, сотрудники участвовали в международных, всесоюзных конференциях, симпозиумах. Автопарк пополнился машинами разных марок для полевых и экспедиционных работ, свыше 100 семей сотрудников улучшили жилищные условия и др.

После увольнения О. В. Макеева постановлением Президиума АН СССР от 4 сентября 1969 г. № 774 председателем Президиума БФ СО АН СССР был назначен д. вет.н., проф. Василий Родионович Филиппов (26.04.1913 - 03.09.1993). 
Отечественная история

В. Р. Филиппов родился в 1913 г. в улусе Ирхидей Боханского района Иркутской области. Трудовую деятельность начал в 1928 г. в колхозе «Адуша-Ажал», одновременно учился в Осинской школе крестьянской молодежи в улусе Ирхидей. В 1931-1933 гг. работал заведующим отделом культуры и пропаганды, заместителем секретаря Боханского аймачного отдела комсомола в с. Бохан, в 1933-1934 гг. - заведующим отделом кадров «Скотимпорта» г. Верхнеудинска. В 1934-1935 гг. - политрук отдела пожарной охраны (ОПО) НКВД БурАССР, студент Улан-Удэнского вечернего рабфака г. Улан-Удэ, в 1935-1939 гг. - студент Бурятского сельскохозяйственного института. Получив квалификацию ветеринарного врача, с 1939 по 1941 г. работал ассистентом в институте.

В 1941 г. служил в военной окружной бактериологической лаборатории Забайкальского военного округа. В 1941-1942 гг. - заведующий сельскохозяйственным отделом Бурятского обкома КПСС, в 1942-1945 гг. - 1-й секретарь Хоринского райкома КПСС. В 1945 г. поступил в аспирантуру Харьковского ветеринарного института. В 1947 г. закончил аспирантуру с защитой диссертации на ученую степень кандидата биологических наук по теме «Сравнительное изучение стимулирующего действия гистолизатов академика М. П. Тушнова и антиретикулярной цитотоксической сыворотки академика А. А. Богомольца на продукцию агглютининов» [НА БНЦ СО РАН. Ф. 3. Оп. 4. Д. 35 (л/д)]. В 1949 г. ему присвоено звание доцента по кафедре «Патологическая физиология» БСХИ. В 1953 г. защитил диссертацию на ученую степень доктора ветеринарных наук по теме «Влияние антитуберальной невроцитоксической сыворотки на иммунобиологические свойства организма». В 1954 г. ему присвоено ученое звание профессора.

Более 22 лет (с 1947 по 1969 г.) трудовая деятельность В. Р. Филиппова была связана с Бурятским сельхозинститутом: он работал доцентом, профессором, заведующим кафедрой патологической физиологии; в 1947-1948 гг. - деканом ветеринарного факультета, 1950-1951 гг. - заместителем директора по учебной и научной работе, 1952-1958 гг. - ректором БСХИ.

В 1958-1960 гг. он занимал должность председателя Совета Министров Бурятской АССР, в 1960-1962 гг. - секретарь Бурятского обкома КПСС. В. Р. Филиппов, возглавляя Совет Министров Бурятской АССР и Бурятский обком КПСС, участвовал в принятии основополагающих решений об организации и развитии сети академических учреждений Бурятии.

В 1962 г. он вернулся на научно-педагогическую работу и до 1969 г. работал ректором Бурятского сельскохозяйственного института. Под его руководством в должности директора (1952-1957), затем ректора (1962-1969) бывший зооветеринарный институт, состоящий из двух факультетов и имевший всего 200-300 студентов, был преобразован в крупный сельскохозяйственный институт с семью факультетами, насчитывающий в 1969 г. более 7 тыс. студентов. В период его руководства были подготовлены высококвалифицированные научные кадры (120 кандидатов и 10 докторов наук), создана хорошая материально-техническая база, построен студенческий городок, состоящий из комплекса учебных, жилых, вспомогательных зданий и сооружений.

Профессором В. Р. Филипповым опубликовано свыше 35 научных трудов, в т. ч. 3 монографии. Его научные работы посвящены изучению иммунитета домашних животных, обмену веществ у крупного рогатого скота в онтогенезе, биологической адаптации организма продуктивных животных к условиям Забайкалья и др.

За достигнутые успехи в развитии высшего образования и науки Василий Родионович был награжден орденами Ленина и Октябрьской революции, медалями «За доблестный труд», «За трудовое отличие», «За доблестный труд в Великой Оте- 
чественной войне», золотой медалью ВДНХ «За успехи в народном хозяйстве СССР». В 1966 г. ему было присвоено почетное звание «Заслуженный деятель науки и техники Бурятской АССР», а в 1973 г. - «Заслуженный деятель науки РСФСР».

В. Р. Филиппов избирался депутатом Верховного Совета CCCP IV, V, VI созывов, Верховного Совета Бурятской АССР III, V созывов, был делегатом XXI и XXII съездов КПСС; на XXII съезде КПСС избран кандидатом в члены ЦК КПСС.

В период его руководства в Бурятском филиале СО АН СССР велись научные исследования по новым направлениям: геоморфологии берегов Байкала, экономике рационального использования природных ресурсов бассейна оз. Байкал и др. [Научные центры 2006: 54]. В этот период филиал посетили известные зарубежные монголоведы из Чехословакии, Франции, ГДР, МНР; организована выездная сессия объединенного ученого совета по биологическим наукам СО АН СССР с участием академиков, членов-корреспондентов, ученых АН СССР.

В. Р. Филипповым проведена большая работа по организации Геологического института БФ СО АН СССР на базе отдела геологии, созданы патентный отдел, метрологическая служба. В эти годы в филиал были приглашены высококвалифицированные специалисты с ученой степенью: М. В. Мохосоев, В. Э. Рыгдылон, Э. И. Матханов, Д. И. Царев и др. Улучшилась материальная база филиала: построены здания БИОН, детского сада на 280 мест, в 1972 г. сдан в эксплуатацию 80-квартирный жилой дом и т. д.

20 мая 1975 г. в своем заявлении секретарю Бурятского обкома КПСС А. У. Модогоеву о назначении ему пенсии союзного значения он писал: «Вся моя жизнь, общественно-политическая, государственная и научная деятельность, как комсомольцев, коммунистов и всех трудящихся города и деревни моего поколения, была посвящена строительству социализма и коммунизма в нашей родной стране. Шли годы за годами, почти не заметив, я стал человеком шестидесятилетнего возраста, проще говоря, гражданином СССР пенсионного возраста...» [НА БНЦ СО РАН. Ф. 3. Оп. 4. Д. 35 (л/д)].

Постановлением Президиума СО АН СССР от 29 апреля 1975 г. № 267 председателем Президиума БФ СО АН СССР был назначен д. х. н., проф. Маркс Васильевич Мохосоев (21.01.1932 - 30.06.1990).

М. В. Мохосоев родился 21 января 1932 г. в с. Аларь Аларского района Иркутской области, в семье колхозника. С 1939 г. учился в Аларской средней школе и окончил 9 классов. В 1949 г. окончил Голуметскую среднюю школу Иркутской области и поступил в Томский политехнический институт. После окончания института в 1949 г. был направлен на предприятие п/я 21 в г. Стерлитамак, где работал старшим мастером производства. В 1956 г. направлен в Кяхтинский индустриальный техникум заместителем директора по учебной работе. В 1958 г. поступил в аспирантуру при Московском институте тонкой химической технологии по специальности «химия и технология редких и рассеянных элементов». В 1961 г. защитил кандидатскую диссертацию и был направлен в Донецкий филиал научно-исследовательского института химических реактивов и особо чистых химических веществ (ИРЕА, позже ВНИИ химических реактивов и особо чистых веществ для электронной техники), где работал руководителем группы, заведующим лабораторией неорганического синтеза и высокочистых веществ [Там же. Д. 679 (л/д)]. В июле 1965 г. переведен в Донецкий государственный университет, где работает заведующим кафедрой неорганической химии и деканом химического факультета. В 1970 г. защитил докторскую диссертацию в Институте проблем материаловедения Украинской CСР. В ноябре 1971 г. утвержден в ученом звании профессора.

По приглашению переведен в 1972 г. в Бурятский филиал СО АН СССР заведующим отделом химии редких элементов Института естественных наук БФ СО АН 
СССР (ИЕН). В апреле 1974 г. назначен заместителем директора по научной работе, в марте 1975 г. - директором ИЕН, а в апреле 1975 г. - председателем Президиума БФ СО АН СССР. С апреля 1987 по 30 июня 1990 г. работал заведующим лабораторией химии редких элементов ИЕН [НА БНЦ СО РАН. Ф. 3. Оп. 4. Д. 679 (л/д)].

М. В. Мохосоев автор 356 научных работ, посвященных синтезу и изучению физико-химических свойств неорганических соединений, в т. ч. 11 монографий и 45 авторских свидетельств на изобретения. Он внес большой вклад в химию редких элементов, многие его разработки получили научное признание и широкую известность, внедрены в производство. Им разработаны методы получения молибдатов, вольфраматов, халькогенидов. М. В. Мохосоев является одним из авторов впервые примененного в стране в 1958 г. метода плавки для очистки сложных неорганических веществ. Им проведены исследования по разработке научных основ комплексной переработки рудных (редкометалльных) месторождений, что имело большое значение в решении проблем рационального использования природных ресурсов.

По научной работе он побывал во многих странах мира: Индии, ГДР, МНР, Японии, НРБ, ЧССР, Франции, КНДР, являлся вице-президентом Общества советскоиндийской дружбы, вел большую работу по координации научных исследований как в республике, так и за рубежом.

М. В. Мохосоев активно вел работу по подготовке научных кадров и воспитанию студенческой молодежи, уделял много внимания организации и проведению научно-исследовательской и учебно-методической работы среди студентов в Донецком, Кабардино-Балкарском университетах, Восточно-Сибирском технологическом университете. Под его руководством было подготовлено более 30 кандидатов наук.

Он являлся членом ряда научных советов АН СССР и СО АН СССР, ответственным редактором тематического сборника «Химия и технология молибдена и вольфрама». В декабре 1981 г. М. В. Мохосоев избран членом-корреспондентом АН СССР.

Член КПСС с 1957 г., трижды избирался членом Бурятского обкома КПСС (1976, 1979, 1981 гг.). В 1980 г. избран председателем Верховного Совета Бурятской АССР, был депутатом двух созывов. В характеристике-рекомендации для представления к назначению председателем филиала на новый срок было отмечено: «За достигнутые успехи в выполнении заданий 10-й пятилетки по развитию советской науки и техники и внедрение результатов исследований в народное хозяйство награжден орденом “Знак Почета”. Также он награжден медалью “За доблестный труд” в ознаменование 100-летия со дня рождения В. И. Ленина, “За строительство БайкалоАмурской магистрали”. В 1980 г. ему присвоено почетное звание “Заслуженный деятель науки Бурятской АССР"» [Там же. Л. 71].

Обладая хорошими организаторскими способностями, Маркс Васильевич сумел проделать большую научную и организационную работу в филиале. Под его руководством институты филиала достигли заметных успехов в научных исследованиях, подготовке кадров высшей квалификации, по укреплению связи науки с вузами и производством. Он способствовал развитию междисциплинарных исследований на стыке физики, математики и химии, создал в БИЕН новую лабораторию химии и технологии минерального сырья [Научные центры 2006: 26].

В годы его руководства был организован отдел биологически активных веществ индо-тибетской медицины при БФ СО АН СССР, а отдел биологии БФ СО АН СССР преобразован в Институт биологии, создан специализированный совет с правом защиты кандидатской диссертации по специальности «монгольские языки», активно функционировали экспериментальные базы и научные стационары на территориях Селенгинского, Еравнинского, Баунтовского, Баргузинского и других районов республики. Динамично расширялись научные связи с учеными зарубежных стран: ГДР, НРБ, МНР, Вьетнама, Лаоса, Шри-Ланка, Кампучии, Индии, Японии, США. 
В характеристике для представления М. В. Мохосоева к награждению орденом «Знак Почета» В. Ц. Найдаков писал: «... Чуткий, отзывчивый товарищ, плодовитый ученый и умелый организатор науки, он пользуется заслуженным авторитетом и уважением в коллективе филиала и среди широкой общественности...» [НА БНЦ СО РАН. Ф. 3. ОП. 4. Д. 679 (л/д). Л. 62].

В январе 1987 г. председатель Сибирского отделения РАН академик АН СССР В. А. Коптюг в обращении к руководству Бурятского обкома КПСС рекомендовал на пост руководителя Президиума БФ СО АН СССР чл.-кор. АН СССР Н. Л. Добрецова. Рекомендация была учтена и 15 апреля 1987 г. Николай Леонтьевич был назначен председателем Президиума БФ СО АН СССР. Он руководил филиалом непродолжительный период - с 1987 по 1989 г.

Николай Леонтьевич Добрецов родился 15 января 1936 г. в Ленинграде, в семье научных сотрудников: отец - профессор Ленинградского политехнического института, заведующий лабораторией Ленинградского физико-технического института; мать - геолог. Учился в школе в Алма-Ате, Ленинграде. В 1953 г. окончил с медалью среднюю школу и поступил в Ленинградский горный институт. В 1957 г. окончил с отличием институт, получил специальность инженера-геолога. С 1947 по 1960 г. работал геологом, начальником партии Алтайской геолого-съемочной экспедиции. С 1960 г. Н. Л. Добрецов трудился в Институте геологии и геофизики СО АН СССР на должностях младшего, а затем старшего научного сотрудника, заведующего лабораторией метаморфических формаций (с 1972 по 1980 г.). В 1980 г. Н. Л. Добрецов назначен директором Геологического института БФ СО АН СССР.

Работая под руководством академика В. С. Соболева, в 1963 г. он защитил кандидатскую диссертацию по проблеме месторождений жадеита, а в 1970 г. - докторскую диссертацию на тему «Глаукофансланцевые и эклогит-глаукофансланцевые комплексы СССР и их генезис». В 1971-1972 гг. работал в Институте тектоники и геофизики ДВНЦ АН СССР в должности заведующего отделом магматических метаморфических формаций. В 1974 г. утвержден в ученом звании профессора. В 1984 г. Н. Л. Добрецов избран членом-корреспондентом АН СССР. В 1966-1980 гг. он преподавал по совместительству в Новосибирском государственном университете.

Н. Л. Добрецов - крупный специалист в области минералогии, петрологии и геологии, автор свыше 280 научных работ, в т. ч. 22 зарубежных публикаций. Один из инициаторов и организаторов нового направления в геологии - создания международных карт метаморфизма Европы (1973) и Азии (1975). Он внес важнейший вклад в создание учения о метаморфических фациях и формациях, месторождения полезных ископаемых, связанных с метаморфизмом, показал их значение на примере колчеданных месторождений полиметаллов, золота и других металлов. За монографии по фациям метаморфизма и карту фаций СССР в 1976 г. вместе с академиком В. С. Соболевым и другими его учениками он удостоен Ленинской премии в области науки.

Н. Л. Добрецов внес крупный вклад в петрологическое обоснование глобальной тектоники, в частности в разработку индикаторной роли глаукофановых сланцев и офиолитов, глобальной эволюции эндогенных геологических процессов. Под его руководством в Геологическом институте БФ СО АН СССР были проведены фундаментальные и прикладные исследования, ориентированные на развитие производительных сил Сибири. В их числе работы по расширению сырьевой базы золотодобычи в Бурятии, а также Джидинского комбината, Озернинского рудного узла, и др. Будучи директором института, а затем председателем Президиума БФ $\mathrm{CO}$ АН СССР, Н. Л. Добрецов проводил большую работу по подготовке научных кадров, среди его учеников на тот момент было 3 доктора наук, более 20 кандидатов. Он являлся соавтором трех учебников для студентов НГУ. 
Отечественная история

Н. Л. Добрецов вел огромную научно-организационную, общественную работу. В 1973-1981 гг. принимал участие в международных проектах «Офиолиты», «Металлогения докембрия», «Доюрская эволюция Восточной Азии». В 1976 г. назначен заместителем межведомственного петрографического комитета, председателем комиссии по метаморфизму и метаморфогенному рудообразованию петрокомитета, являлся членом комиссии по петрологии пород океанского дна, заместителем председателя специализированного совета по защите докторских диссертаций, членом многих советов по защите диссертаций.

Член КПСС с 1981 г., избирался депутатом Улан-Удэнского горсовета, за активное участие в общественной жизни научного сообщества награжден Почетными грамотами Президиума АН СССР, СО АН СССР и филиала, медалью «За строительство Байкало-Амурской магистрали», орденом Трудового Красного Знамени [НА БНЦ СО РАН. Ф. 3. Оп. 4. Д. 696, 1153 (л/д)].

За период его руководства Президиум АН СССР принял постановление «О перспективах развития Бурятского филиала СО АН СССР на период до 2000 г.», которое существенно расширило функции ведущего академического учреждения как координатора научных исследований в регионе и наметило долговременные перспективы его развития [Там же. Д. 1153 (л/д); Научные центры 2006: 55]; в филиале была создана кафедра философии и иностранных языков, организован отдел проблем прочности и надежности при Президиуме БФ СО АН СССР. В 1987 г. Николай Леонтьевич был избран в действительные члены Российской академии наук.

В 1989 г. Н. Л. Добрецова пригласили в Новосибирск, в Президиум СО АН СССР, где он работал заместителем председателя отделения, а в 1997 г. избран председателем Сибирского отделения РАН. Занимая высокие посты в руководстве СО РАН, Николай Леонтьевич продолжал оказывать методическую и организационную поддержку Бурятскому научному центру.

После отъезда академика Н. Л. Добрецова постановлением Президиума СО АН ССР от 27 октября 1989 г. № 488 председателем Президиума БНЦ СО АН СССР был назначен д. ф. н., проф. Василий Цыренович Найдаков (15.06.1928 - 08.04.1997).

В. Ц. Найдаков родился 15 июня 1928 г. в с. Торы Тункинского аймака Бурятской АССР в семье служащего. После окончания средней школы в 1945 г. поступил в Улан-Удэнское театрально-музыкальное училище. В 1954 г. окончил Иркутский государственный университет с присвоением квалификации «преподаватель русского языка и литературы». В 1954-1959 гг. преподавал на кафедре русской и зарубежной литературы ИГУ. В 1959-1963 гг. работал младшим научным сотрудником, заведующим отделом искусств, ученым секретарем Бурятского комплексного научно-исследовательского института СО АН СССР. В 1959 г. вышла из печати его монография «Бурятская драматургия», которую он представил на соискание ученой степени кандидата филологических наук и успешно защитился в 1960 г. при Институте востоковедения АН СССР.

В 1963-1966 гг. В. Ц. Найдаков работал заместителем заведующего идеологическим отделом и заведующим отделом науки и учебных заведений Бурятского обкома КПСС. С марта 1966 г. Василий Цыренович - заведующий сектором искусствоведения БИОН БФ СО АН СССР, в 1970 г. назначен заместителем директора БИОН, в октябре 1975 г. - заместителем председателя Президиума Бурятского филиала СО АН СССР.

В 1980 г. В. Ц. Найдаков защитил диссертацию на соискание ученой степени доктора филологических наук и был назначен директором Бурятского института общественных наук. В 1983 г. утвержден в ученом звании профессора.

В. Ц. Найдаков - крупный специалист в области литературоведения и искусствоведения, автор 210 научных трудов, в т. ч. 27 монографий [Там же. Д. 1152 (л/д). Л. 128]. Основные направления его исследований - история бурятской литературы 
и театрального искусства, взаимодействие традиций национального культурного наследия и современной культуры, разработка вопросов теории литературы народов Российской Федерации. Им изучены проблемы становления, развития и распада в последние годы бурятской литературы, дана классификация советской национальной литературы по типологии ее исторического развития, проведено исследование театрального и киноискусства Монголии. Как член Союза писателей СССР и исследователь, он активно выступал в печати по вопросам современной бурятской прозы, драматургии и поэзии. О его научных трудах писали: «В работах В. Ц. Найдакова впервые полно освещена история советской литературы 1950-1960-х гг., традиции Горького в ней, бурятского драматического театра и драматургии. Его научным исследованиям свойственны глубина и добросовестность в разработке поднимаемых проблем, они всегда устремлены в художественную практику наших дней...» [НА БНЦ СО РАН. Ф. 3. ОП. 4. Д. 1152 (л/д)].

Будучи директором института, В. Ц. Найдаков вложил много труда в улучшение его деятельности, повышение эффективности научных исследований, создание и укрепление работоспособного научного коллектива. Под его руководством в БИОН выполнен цикл исследований по вопросам становления и развития различных видов и жанров литературы и искусства Бурятии. Он активно участвовал в подготовке научных и преподавательских кадров, им подготовлен 1 доктор наук и 14 кандидатов.

В. Ц. Найдаков активно вел научно-организационную и общественную работу как член ряда научных и координационных советов АН и СО АН СССР, РАН и СО РАН, президиума ассоциации востоковедов, советской части комиссии по сотрудничеству РАН и АН Монголии в области общественных наук, являлся членом исполкома Международной ассоциации монголоведов, председателем диссертационного совета по защите докторских и кандидатских диссертаций. В разные годы он избирался секретарем партийного комитета филиала, членом Бурятского обкома и горкома КПСС, депутатом Улан-Удэнского горсовета, являлся председателем правления бурятской организации общества «Знание».

За выдающиеся заслуги в области науки в 1975 г. В. Ц. Найдакову присвоено звание «Заслуженный деятель науки Бурятской АССР». В 1976 г. по итогам IX пятилетки он награжден орденом «Знак Почета», а в 1978 г. - Почетной грамотой Президиума Верховного Совета Бурятской АССР. За успехи в проведении научных исследований, подготовке высококвалифицированных научных кадров и большой вклад в развитие производительных сил награжден орденом Трудового Красного Знамени. В. Ц. Найдаков - «Заслуженный деятель науки Российской Федерации», действительный член Петровской академии наук и искусств.

В рекомендательном письме на выдвижение кандидатуры В. Ц. Найдакова на избрание членом-корреспондентом АН СССР академик В. П. Алексеев, директор Института археологии АН СССР, писал: «При многообразии и масштабности научной деятельности В. Ц. Найдаков никогда не замыкался в ее рамки. И речь идет не о занимавшихся им и занимаемых в настоящее время административных постах, а о широком общественном размахе и резонансе его культурной работы, о разносторонних связях, которые он устанавливал всегда с представителями других дисциплин, о поддержке любых прогрессивных начинаний в области бурятиеведения, монголоведения и сибирской науки в целом, о высокой ответственности, с которой он подходит к любой форме общественного служения» [Там же. Л. 126].

В период его руководства Бурятский научный центр, как все другие научные центры, столкнулся с проблемой сохранения инфраструктуры, оттоком кадров, нехваткой финансирования и т. д. В этих условиях Президиум БНЦ выработал особую программу действий, которая учитывала новые реалии: в Республике Бурятия был создан Фонд науки. С 1993 г. Министерство образования РБ стало курировать науку. 
Исполнительные органы государственной власти РБ выстраивали научно-техническую политику региона, опираясь на разработки ученых БНЦ, и ставили одним из основных приоритетов своей деятельности задачи поддержки научного и образовательного потенциала [НА БНЦ СО РАН. Ф. 3. Оп. 4. Д. 1152 (л/д). Л. 27; Научные центры 2006: 56]. В эти годы был создан Байкальский институт рационального природопользования, сдано в эксплуатацию здание хранилища восточных рукописей и ксилографов, проведены многочисленные международные, всероссийские научные мероприятия: круглые столы, конференции, симпозиумы, в т. ч. заседание $\mathrm{X}$ Международного конгресса космонавтов и астронавтов.

В 1995 г. БНЦ СО РАН возглавил д. г.-м.н., проф. Иван Власович Гордиенко, которого назначили постановлением Президиума СО РАН от 26 мая 1995 г. № 162.

И. В. Гордиенко родился 3 января 1936 г. в с. Жигалово Велико-Михайловского района Курской области, в семье крестьян-колхозников. В автобиографии он пишет: «Мое детство прошло в с. Трактово-Курзан Тулунского района Иркутской области, куда переехали мои родители в связи с общей мобилизацией населения на подъем сельского хозяйства восточных районов» [Текущий архив БНЦ СО РАН, л/д].

После окончания Куйтунской средней школы в 1954 г. поступил на геологический факультет Иркутского государственного университета. После его окончания в 1959 г., получив специальность инженера-геолога, был направлен на работу в Восточно-Сибирский геологический институт СО АН СССР (ныне Институт земной коры СО РАН, г. Иркутск), на должность старшего лаборанта. С тех пор вся творческая трудовая жизнь И. В. Гордиенко связана с работой в Академии наук.

В 1966 г. Иван Власович защитил кандидатскую диссертацию. В 1967 г. перешел по конкурсу в Геологический институт БФ СО АН СССР, где прошел путь от старшего до ведущего научного сотрудника лаборатории петрографии, заведующего лабораторией палеовулканологии. В институте им была организована лаборатория палеовулканологии и тектоники, впоследствии преобразованная в лабораторию геодинамики [Там же].

В 1987 г. защитил диссертацию на соискание ученой степени доктора геолого-минералогических наук. С 1992 г. он профессор кафедры геологии Бурятского государственного университета, а в 1997 г. избран членом-корреспондентом РАН.

И. В. Гордиенко - крупный ученый в области наук о земле (геодинамики, петрологии, вулканологии и региональной геологии), один из основателей нового научного направления - магматической геодинамики. Иван Власович автор и соавтор 212 научных работ, в т. ч. 10 монографий, 22 работы изданы за рубежом. Он соавтор 7 опубликованных геологических карт международного и регионального значения. Им выполнен ряд фундаментальных исследований по всестороннему изучению магматизма различных геодинамических обстановок Центрально-Азиатского и Монголо-Охотского складчатых поясов, в результате чего детально охарактеризованы структурно-вещественные комплексы Палеоазиатского океана, дана их металлогеническая характеристика с позиций современных положений тектоники литосферных плит. И. В. Гордиенко как ученый-геолог открыл на территории Бурятии ряд редкометалльных и редкоземельных проявлений, обосновал верхнепалеозойскую геологическую и, соответственно, металлогеническую эпохи в развитии Забайкалья, составил прогнозные карты на стратегическое бериллиевое и апатитовое (фосфатное) сырье на территории Бурятии [Там же].

На посту председателя Президиума БНЦ СО РАН И. В. Гордиенко проводил активную научную и научно-техническую политику в регионе. В период его руководства началась реструктуризация научных учреждений, вовлекшая научное общество в сложную организационную перестройку всей системы СО РАН. У некоторых институтов были изменены названия, переориентирована направленность иссле- 
дований многих подразделений. В 1997 г. один из старейших институтов - БИЕН прекратил свое существование. Его лаборатории вошли в состав БИРП и вновь организованного ОФП при Президиуме БНЦ [Научные центры 2006: 57]. В трудное время ему удалось сохранить кадры и инфраструктуру БНЦ, выстроить эффективную модель взаимодействия и сотрудничества с республиканскими органами власти, отраслевыми НИИ, вузами. Под его руководством и при непосредственном участии были внедрены и разработаны комплексные РНТП «Бурятия. Наука. Технологии и инновации», «Настоящее и будущее Байкало-Ленского региона», положено начало проведению регионального конкурса РФФИ-Байкал. Он соавтор закона Республики Бурятия «О науке и научно-технической политике».

И. В. Гордиенко вел активную научно-организационную и общественную работу, был членом различных международных, всероссийских и региональных комиссий, комитетов, ученых и диссертационных советов, редколлегий, в т. ч. членом Президиума СО РАН, совета по координации деятельности научных центров РАН, объединенного ученого совета наук о Земле, высшего экономического совета при Президенте Республики Бурятия, заместителем председателя научного совета СО РАН по проблемам озера Байкал. За личный вклад в социально-экономическое развитие Республики Бурятия Ивану Власовичу присвоено звание «Почетный гражданин Республики Бурятия» (2004) [Текущий архив БНЦ СО РАН, л/д].

За успехи в научно-организационной деятельности И. В. Гордиенко присвоены почетные звания «Заслуженный деятель науки Бурятской АССР» (1979), «Заслуженный деятель науки Российской Федерации» (1995), награжден медалями ордена «За заслуги перед Отечеством» II степени (1999), «За заслуги перед Отечеством» IV степени (2007), а также Почетными грамотами Президента и Правительства Республики Бурятия, Правительства Монголии, Президиума РАН, СО РАН и других организаций, присвоено звание «Ветеран труда» (1988).

К 75-летию Ивана Власовича академик В. М. Фомин и чл.-кор. РАН Н. 3. Ляхов писали: «...Ваш большой жизненный и организационный опыт и авторитет ученого заслужили уважение в Бурятском научном центре СО РАН, которым вы руководите с 1995 по 2007 год... Вы являете собой яркий пример современного гармоничного человека - трудолюбивого, азартного поисковика, прекрасного ученого, умелого воспитателя молодых коллег» [Члену-корреспонденту... 2011: 12].

В 2007 г. И. В. Гордиенко покинул пост председателя Президиума БНЦ СО РАН. К этому времени в РАН была введена выборная система председателей научных центров. 20-23 марта 2007 г. на общем собрании СО РАН председателем БНЦ СО РАН избран чл.-кор. РАН Борис Ванданович Базаров [НА БНЦ СО РАН. Ф. 3. Оп. 1. Д. 1074. Л. 4].

Борис Ванданович родился 10 октября 1960 г. в с. Курумкан Курумканского района Бурятской АССР, в семье служащих. По окончании средней школы № 1 г. УланУдэ в 1977 г. поступил на историко-филологический факультет Бурятского государственного педагогического института им. Д. Банзарова, который окончил в 1981 г. с присвоением квалификации преподавателя истории и обществоведения. С 1981 по 1983 г. работал в комсомольских органах. С декабря 1983 г. перешел на преподавательскую работу в Восточно-Сибирский государственный институт культуры. С декабря 1984 по октябрь 1987 г. - аспирант Иркутского государственного университета. В октябре 1987 г. защитил диссертацию на соискание ученой степени кандидата исторических наук. С 1987 по 1995 г. - преподаватель, затем заведующий кафедрой истории Восточно-Сибирского государственного института культуры. В июне 1995 г. защитил докторскую диссертацию в Иркутском государственном университете. В этом же году избран заведующим отделом истории Бурятского института общественных наук СО РАН [Текущий архив ИМБТ СО РАН, л/д]. 
В апреле 1997 г. Борис Ванданович был назначен директором БИОН СО РАН, который впоследствии переименован в Институт монголоведения, буддологии и тибетологии Сибирского отделения Российской академии наук (ИМБТ СО РАН). В этой должности работает по настоящее время.

С марта 2007 по март 2016 г. по совместительству работал председателем Президиума Бурятского научного центра СО РАН.

Б. В. Базаров дважды избирался в депутаты Народного Хурала Республики Бурятия: с 1998 по 2002 г. - депутат Народного Хурала Республики Бурятия II созыва, 2013-2018 гг. - депутат Народного Хурала Республики Бурятия V созыва.

В 2003 г. избран членом-корреспондентом РАН. В 2016 г. решением ученого совета Федерального государственного бюджетного учреждения науки «Институт монголоведения, буддологии и тибетологии Сибирского отделения Российской академии наук» чл.-кор. РАН Борис Ванданович Базаров выдвинут кандидатом для участия в выборах академиков Российской академии наук по отделению историко-филологических наук РАН на вакансию для Сибирского отделения РАН по специальности «история, востоковедение» (протокол № 4 от 12 мая 2016 г.) [Текущий архив ИМБТ СО РАН, Л/д].

В 2011 г. Борис Ванданович избран иностранным действительным членом Академии наук Монголии. В октябре 2016 г. избран академиком Российской академии наук.

Б. В. Базаров - один из ведущих российских ученых в области востоковедения в сфере социально-политической истории монгольских народов. Он - автор 244 научных работ, в т. ч. 17 авторских и коллективных монографий по социально-политической и этнокультурной эволюции Центрально-Азиатского региона. Основными направлениями научных исследований Б. В. Базарова являются история и культура монгольских народов, геополитика и международные отношения, социальное и межкультурное взаимодействие народов Центральной Азии. Б. В. Базаров - один из организаторов современных гуманитарных исследований в Сибири, осуществляет в институте научное руководство по проблемам социально-политической истории Центральной и Восточной Азии, организатор и участник ряда крупных грантовых, экспедиционных и международных научных проектов в области монголоведения и тибетологии, как руководитель крупного востоковедного центра России координирует международные научные связи института с учеными Монголии, Китая, Индии, Японии, Германии, Англии и США в сфере современных монголоведных исследований. Под его руководством ежегодно на базе института проводятся международные конференции по проблемам истории и культуры монголоязычных народов, кочевой цивилизации, традиционной культуре Байкальского региона. Б. В. Базаров плодотворно работает в сфере подготовки кадров ученых высшей квалификации, среди его учеников 14 докторов и 28 кандидатов наук. Является председателем диссертационного совета (Д 003.027.01) при ИМБТ СО РАН по защите диссертаций на соискание ученой степени доктора наук по историческим наукам.

Б. В. Базаров - член редколлегии журналов «Проблемы востоковедения», «Наука из первых рук» СО РАН, редсовета журналов «Гуманитарные науки в Сибири» СО РАН, «Власть», «Вестник российской нации», главный редактор, председатель редсовета журнала «Вестник БНЦ СО РАН», председатель совета директоров институтов Бурятского научного центра СО РАН, член совета по координации деятельности региональных отделений и региональных научных центров РАН, бюро объединенного ученого совета СО РАН по гуманитарным наукам, председатель докторского диссертационного совета при ИМБТ СО РАН.

За выдающиеся заслуги и большой вклад в развитие российской науки Б. В. Базаров удостоен звания «Заслуженный деятель науки РБ», лауреат Государственной премии РБ, в 2007 г. награжден орденом Дружбы. В 2011 г. отмечен высшим орденом Монголии «Полярная Звезда». 
За время его работы БНЦ СО РАН нарастил научный потенциал по ряду важнейших направлений. Были созданы новые структуры: отделы региональных экономических исследований, междисциплинарных и инициативных научных проектов, на базе отдела физических проблем создан Институт физического материаловедения СО РАН. Значительно активизировалась инновационная деятельность: разработаны проекты по созданию технопарка «Биотехнополис», сейсмоцентра с участием Правительства Республики Бурятия, сформирована перспективная модель новых инновационных объектов на территории БНЦ СО РАН. За 2007-2016 гг. была полностью обновлена материально-техническая база: введен в эксплуатацию зал заседаний БНЦ, где используются цифровые конференц-системы, произведена модернизация центрального узла связи, проведен капитальный ремонт в зданиях БНЦ, ДОУ № 53, обновились стационары, автопарк, введены в строй 2 многоквартирных дома.

В 2013 г. в связи с реформированием системы Российской академии наук учредителем всех научных институтов, расположенных в Бурятии, стало Федеральное агентство научных организаций (ФАНО). Все учреждения, подведомственные ФАНО России, утвердили новые уставы, другие правовые акты, связанные с научной и хозяйственной деятельностью. До процедуры объявления новых выборов председателя БНЦ СО РАН Приказом ФАНО России от 26 февраля 2016 г. № 107 п/0 временно исполняющей обязанности была назначена к. и. н. Галина Дашиевна Базарова.

Г. Д. Базарова родилась 12 октября 1960 г. в с. Михайловка Закаменского района Республики Бурятия. В 1984 г. окончила Новосибирский государственный университет с присвоением квалификации историка. В 1984 г. по распределению приехала в Улан-Удэ. Была принята в Институт общественных наук БФ СО АН СССР на должность стажера-исследователя сектора философии. После окончания стажировки назначена старшим лаборантом сектора истории БИОН. В 1988 г. поступила в очную аспирантуру БИОН, после окончания которой работала младшим научным сотрудником сектора истории, затем научным сотрудником отдела истории, этнологии и социологии Института монголоведения, буддологии и тибетологии СО РАН.

В 1998 г. Галина Дашиевна защитила диссертацию на соискание ученой степени кандидата исторических наук на тему «Формирование и развитие научной интеллигенции Бурятии (1922-1985 гг.)». В августе 1999 г. перешла в Министерство образования и науки Республики Бурятия на должность главного специалиста отдела высшего, среднего профессионального образования и науки. В феврале 2003 г. назначена начальником отдела науки и технологий Министерства образования и науки Республики Бурятия.

Г. Д. Базарова принимала активное участие в разработке различных законопроектов и нормативно-правовых документов, направленных на обеспечение и развитие образовательной и научно-технической политики, инновационной деятельности в Республике Бурятия: законов «О науке и научно-технической политике Республики Бурятия», «Об образовании», «Об инновационной деятельности в Республики Бурятия», а также Концепции развития и реформирования социальной сферы Республики Бурятия, Концепции развития инновационной деятельности в Республике Бурятия, республиканской целевой программы «Развитие образования и науки Республики Бурятия».

Г. Д. Базарова принимала участие в подготовке соглашений между Правительством Республики Бурятия, Российским фондом фундаментальных научных исследований (РФФИ) и Российским гуманитарным научным фондом (РГНФ), внесла свою долю в расширение международного взаимодействия учреждений профессионального образования и науки Республики Бурятия: разработку и реализацию программ сотрудничества, содействие программам международного обмена студентами и преподавателями России и зарубежных вузов, проведение международных 
комплексных научно-исследовательских экспедиций, международных научно-практических семинаров и конференций с участием иностранных ученых.

В сентябре 2012 г. Г. Д. Базарова избрана в состав Президиума БНЦ СО РАН и назначена заместителем председателя Президиума БНЦ СО РАН по науке.

В течение 2016 г. временно исполняла обязанности председателя Федерального государственного бюджетного учреждения науки «Бурятский научный центр Сибирского отделения Российской академии наук».

В феврале 2017 г. на собрании коллектива БНЦ СО РАН Г. Д. Базарова избрана и приказом ФАНО от 2 марта 2017 г. № 155 п10 назначена председателем БНЦ СО РАН.

Г. Д. Базарова - специалист в области исследования исторических процессов развития науки, социальной инфраструктуры, исследований инновационных процессов в регионе. Автор и соавтор 33 научных работ. Основные научные результаты Г. Д. Базаровой касаются истории формирования академической науки в Бурятии, становления и развития научной интеллигенции Бурятии, состояния и перспектив развития научно-образовательного комплекса Республики Бурятия на современном этапе; на основе опыта взаимодействия обозначены новые подходы в международном сотрудничестве в области науки и образования в монгольских обществах; исследована роль научных исследований для становления инновационной инфраструктуры региона.

Г. Д. Базарова принимает активное участие в научных, образовательных советах и комиссиях: член коллегии Министерства образования и науки Республики Бурятия, член Совета по науке и инновациям при Главе Республики Бурятия, член Совета директоров организаций, отнесенных к ведению Сибирского ТУ Министерства образования и науки Российской Федерации, член редколлегии журнала «Вестник Бурятского научного центра СО РАН».

За успехи в области науки и образования, активное участие в общественной жизни научного общества Галина Дашиевна удостоена наград и поощрений: «Почетный работник высшего профессионального образования Российской Федерации»; Почетных грамот Министерства образования и науки Республики Бурятия, Правительства Республики Бурятия, благодарности Президента Республики Бурятия.

\section{Источники и литература}

Научный архив БНЦ СО РАН (НА БНЦ СО РАН). Ф. 3. ОП. 4. Бурятский филиал СО АН СССР - Бурятский научный центр СО РАН.

Научные центры СО РАН. - Новосибирск: Гео, 2006. - С. 439.

Члену-корреспонденту РАН Ивану Власовичу Гордиенко - 75 лет // Наука Сибири. 2011. - № 1-2. - C. 12.

\section{References}

Nauchnyj arhiv BNC SO RAN (NA BNC SO RAN): F. 3. Op. 4. Buryatskij filial SO AN SSSR - Buryatskij nauchnyj centr SO RAN.

Nauchnye centry SO RAN. - Novosibirsk: Geo, 2006. - S. 439.

Chlenu-korrespondentu RAN Ivanu Vlasovichu Gordienko - 75 let // Nauka Sibiri. - 2011. № 1-2. - S. 12 . 